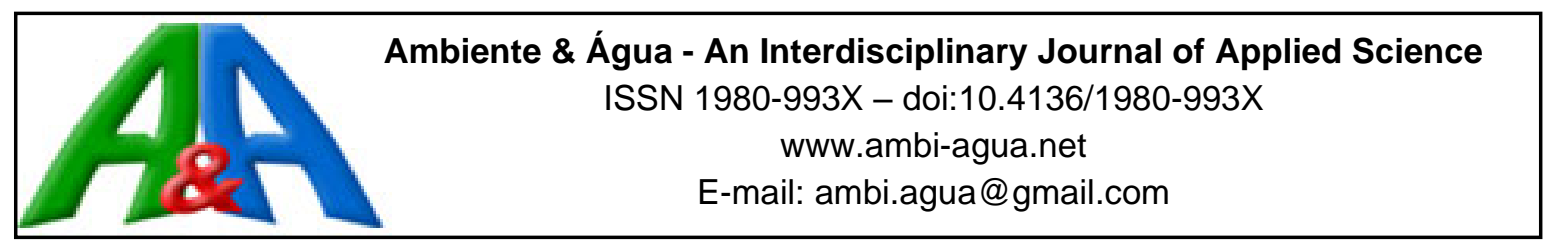

\title{
City, history, and memory: from a destroyed environment to a constructed one. A case study of Natividade da Serra, state of São Paulo, Brazil
}

\author{
ARTICLES doi:10.4136/ambi-agua.2548
}

Received: 21 Aug. 2020; Accepted: 21 Sep. 2020

\author{
Mauro Castilho Gonçalves* ${ }^{(D}$; Michele Rezende Santos ${ }^{(D)}$;ivian Ciapina \\ Programa de Pós-Graduação em Ciências Ambientais (PPGCA). Universidade de Taubaté (UNITAU), \\ Estrada Municipal Doutor José Luiz Cembranelli, n5000, CEP: 12081-010, Taubaté, SP, Brazil. \\ E-mail: michelerezendesantos@gmail.com, vivianciapina@gmail.com \\ *Corresponding author. E-mail: mauro_castilho@uol.com.br
}

\begin{abstract}
Between 1973 and 1974, the city of Natividade da Serra, state of São Paulo, was relocated in order to provide space to construct a hydroelectric dam for power generation. Based on the idea that the relationship between society and physical space acts to shape and influence the culture of a society, we conducted this study with the principal objective of analyzing the social impacts on the local community by highlighting the cultural transformations provoked by the restructuring of a space that was constructed over the period of a century. By conducting a qualitative analysis of data from the document repository of the City Hall and Parish of Our Lady of the Nativity (Nossa Senhora da Natividade), and from oral sources (descriptions collected through oral history), we elaborated a representative image of daily life in the city as it existed before the restructuring. This reconstruction started with the process of destruction and then proceeded to describe the reorganization of the community in the new space, as well as detailing perceptions of the city as a place that has passed through multiple historical experiences. By relating the data obtained from the written and oral sources to the historical context, we attempted to reveal the political, cultural, and ideological dimensions involved in this process of manipulation of inhabited space. We conclude that the innumerous implications caused by the abrupt transformation of this space has altered the customs and forms of sociability of the population. The analysis of the reasons and motivations for the disappearance of the city suggests that, even if only implicitly, this cultural transformation was desired by those who were in power in Brazil at that moment in time.
\end{abstract}

Keywords: Natividade da Serra, Paraibuna Hydroelectric Dam, Space.

\section{Cidade, história e memória: do ambiente destruído ao espaço construído. $O$ caso de Natividade da Serra, SP}

\section{RESUMO}

Entre os anos de 1973 e 1974, a cidade de Natividade da Serra, SP foi realocada para dar lugar a uma represa para servir a uma usina hidrelétrica. Com base na ideia de que a relação existente entre a sociedade e o espaço age na conformação da cultura, efetuamos um estudo de caso cujo objetivo principal foi analisar o impacto social deste processo sobre a comunidade 
local, enfatizando as transformações culturais provocadas pela reestruturação do espaço historicamente construído. Partindo de análise qualitativa dos dados encontrados nas fontes escritas (acervo documental do Executivo Municipal e da Paróquia Nossa Senhora da Natividade) e orais (relatos coletados através do método da história oral) pudemos elaborar um quadro representativo do cotidiano da antiga cidade, de seu processo de destruição e de reorganização da comunidade no novo espaço - bem como perceber a cidade como o lugar de construção das múltiplas experiências históricas. Ao relacionarmos os dados obtidos nas fontes às informações sobre o contexto histórico, procuramos desvendar as dimensões políticas, culturais e ideológicas envolvidas neste processo de manipulação do espaço habitado. Concluímos que as inúmeras implicações trazidas pela transformação abrupta do espaço alteraram os costumes e as formas de sociabilidade da população. A análise das razões e motivações para o desaparecimento da cidade sugeriu que, ainda que de forma implícita, esta transformação cultural era desejada por aqueles que detinham o poder no país.

Palavras-chave: espaço, Natividade da Serra, usina hidrelétrica de Paraibuna.

\section{INTRODUCTION}

The municipality of Natividade da Serra, situated in the region of Vale do Paraíba Paulista, was founded in the middle of the 19th century. In the decade of the 1970s, slightly more than ten percent of its territory was inundated to construct a reservoir for a hydroelectric dam. Two of its villages, a district and the urban area of the city were affected by the waters. Between 1973 and 1974, the old city was destroyed and a new municipal seat was installed about one kilometer from the old one. The new municipal seat was modeled on the architectural and urbanistic patterns of the new period, within the limits imposed by the availability of time and financial resources.

The case of Natividade da Serra became emblematic. The modification of the space did not occur following the new objective necessities that were emerging in that period, but rather obeyed factors that were external to the local community. One of the questions that this research raised was, "would it be possible to preserve a pre-existing urban scenario in a new, recentlycreated form"? In order to understand the many aspects of the relocation of this city, research was conducted regarding the political, cultural, and ideological situation of Natividade da Serra from 1950 to the end of the 1980s. The objective was to examine how the urban space before the inundation was constituted and how the relocation was perceived by the indigenous population.

This research is linked to discussions on the social impacts caused by immense infrastructure projects that are executed through a developmentalist vision. According to Fausto (1996), projects of this nature have been part of Brazilian history during decades, the undertaking of which has been intensified in light of the historical emergence of the industrial model, which has been the paradigm of progress since the end of the 1950s.

The relationship between history and space is described in pertinent literature, and the events and processes that it relates are analyzed from a chronological and geographical approach. The action of man in the course of time happens in a specific space, but the inhabited space is not just the environment in which men construct their historical reality because he himself is a social construction (Lefebvre, 1969; Fenelon, 2000; Rykwert, 2004).

According to Tuan (1983), through this experience, these subjects are able to confer emotional value to a specific space, transforming it into "place" - a type of refuge where one can seek out comfort and security. The term 'place' is used by geographers in opposition to the word 'space', which is understood as something that is limitless, and that by allowing for liberty of movement implies a constant necessity of choices and decisions. 
According to Bosi (1994), subjects can also establish a relationship with space that is directly associated with their experience as members of a social group. This experience transforms a city into the territory of one group or another. Oftentimes, different groups confer different meanings to the same space, based on the experience of each one. In this context, the experience of the individual and the group confers a symbolic dimension to the forms of a city and creates an emotional map that reflects the social relations established in the constructed environment.

\section{MATERIALS AND METHODS}

The complete body of documents used in this investigation is available in three institutions: the City Hall, local Catholic church (local parish) and the Energy Company of São Paulo S/A - (CESP, the previous state company that was responsible for the construction of the reservoir, which was divided into several private companies that still exist).

The collection of documents, which are maintained by the City Hall, are in a deplorable state of conservation. The goal of the methodological procedure was to select only the documents that were relevant to this research, but in order to do so a survey of all the available documents was initially conducted. This procedure resulted in the elaboration of a catalog of the entire collection of documents.

A catalog of a collection of documents is an essential item for historical research (Glénisson, 1961), and in the case of the current research the catalog was elaborated using Microsoft Excel 2007, wherein the origin of the document, its type, period of production, and place of storage were registered.

A decision was made to begin this cataloging by examining only official correspondence of the City Hall. Two reasons motivated this decision: first, the poor physical state in which these documents were found; and second, the nature of the information registered in them. As a function of the problems associated with conservation of these documents as explained above, the series of the Official Expedited Letters from 1950 to 1980 is one of the few resources that is relatively continuous and that also permits a qualitative analysis.

Oral history was the second methodological resource used as a method of historical research (François, 2002; Amado and Ferreira, 2002). This procedure, however, allowed for partial glimpses of the reality of the historical period - a complex plot which partially reveals itself in the meanings conferred by the subjects to their social practices (Khoury, 2001).

Narratives that were symbolic of the diversity of perspectives of reality were collected and organized to attempt to understand them, not as a deviation from a standard pattern, but as part of a constituted reality. In this context, seven people were interviewed who had lived through both stages of the modification of the urban environment, namely, before and after the inundation of the city. In order to organize the responses of the interviewees, a set of questions was used for the interviews, which was structured along the themes: Vila Velha (daily life and space), its disappearance, and the new city.

\section{RESULTS AND DISCUSSION}

At the beginning of the second half of the 20th century, the municipality of Natividade da Serra had about 16,000 inhabitants. The rural population was about $90 \%$ of this total and was responsible for the largest portion of economic wealth possessed by the city - its agricultural and cattle ranching production - which was based on cultivation of corn, beans, cassava, rice, tobacco, and sugar cane, which were all used for consumption by the municipality itself. Later, dairy farming became important, and this production was used by the dairy product factories of the region of the Middle Paraíba Paulista.

The municipality was composed of two urban nuclei: the municipal seat and the district of 
Bairro Alto. There were also many rural neighborhoods and nuclei with different demographic concentrations spread across its vast territory (about $800 \mathrm{~km}^{2}$ ). The municipality was traversed by numerous rivers and streams, and for this reason depended not only on many municipal roads and bridges but also on barges to connect the rural population with the municipal seat.

The documents consulted, especially the official expedited letters from the City Hall (1964-1971), revealed a poor urban population that was lacking in basic necessities such as public sanitation, health care, and education. In 1970, of a total of 483 buildings in the city, just 172 had running water, and only five were connected to sewer lines.

Table 1 shows the evolution of the population between the years1950 and 1970.

Table 1. Evolution of the native population between 1950-1970.

\begin{tabular}{lccc}
\hline & $\mathbf{1 9 5 0}$ & $\mathbf{1 9 6 0}$ & $\mathbf{1 9 7 0}$ \\
\hline RURAL POPULATION & 12,923 & 12,442 & 8,576 \\
URBAN POPULATION & 1,100 & 1,400 & 1,463 \\
TOTAL POPULATION & 15,973 & 15,802 & 10,039
\end{tabular}

Source: Natividade da Serra (1964-1971, p. 174; 1971-1975, fl. 56).

These data reveal a significant reduction in the rural population - which was not equal in magnitude to the increase in the native urban population - exactly during the period in which industrialization was advancing into the cities of the Middle Paraíba region in São Paulo, and in which there was a considerable increase in the populations of these large urban centers.

In order to sustain the indices of industrial development of the Middle Paraíba region in the decades of the 1960s and 1970s, large investments were made in energy production to satisfy the demand of large factories. According to Ricci (1996), energy production in the Paraíba Valley in São Paulo was done by many small companies which took advantage of the hydropower potential in the region but had reduced capacity for energy generation and distribution. Throughout Brazil in this period, there were hydroelectric plants that had been created by industries to meet their own energy demands. Such was the case of the Taubate Industrial Company (C.T.I.), whose machinery was moved by energy produced by the hydroelectric plant of the company, which was installed in the city of Redenção da Serra, very near Natividade da Serra.

In an attempt to contain the successive episodes of flooding of the rivers of this region during the rainy season, it was necessary to intervene using specialized engineering techniques to streamline the process of controlling the waters. The construction of a hydroelectric dam would solve two problems with one solution. Besides the production of electrical energy, the damming up of the inconstant rivers (Paraibuna, Paraitinga and Lourenço Velho) using dikes, polders, and dams, would facilitate efficient regulation of water levels, thus saving large areas of fertile soil for planting.

Ricci (1996) affirms that this situation was the motivation for the construction of the Paraibuna hydroelectric plant, a project that was led by the state company CESP. However, for the plant to exist the city had to be submerged. Furthermore, Natividade was not the only city that was affected, as Paraibuna and Redenção da Serra also suffered loss of area, but Natividade da Serra was the only one that lost its entire urban area.

Since it was a small, rural city with little potential for industrial development due to its location, Natividade did not fit the ideas of the developmentalists who were in power in Brazil. For a government dominated by an elite class that based their actions on the beliefs of the developmentalists, a city such as Natividade da Serra, without much contribution to the regional economic scenario, could be sacrificed for the greater good, which was the necessary and 
inevitable development of industrial areas with more dynamic economies.

Although the planning for this project stipulated that the damming of these rivers would affect only a portion of the territory of Natividade da Serra, most likely, for the reason of the greater good, the elimination of the entire municipality was considered, according to official documents published by the City Hall and the Ministry of the Interior in 1968. In this case, the areas that were not submerged would have been assimilated by neighboring municipalities.

The analysis of the official documents showed that the necessity to guarantee the construction of a new city would have been understood by the City Hall and the state government. Official letters expedited by the City Hall, starting in 1973, demonstrate the insistence of local authorities in demanding just compensation from the state government to guarantee the functioning of state public offices in the city.

Rivers and streams that ran through the region passed near the city, and in some cases went through the backyards of some houses. Most of the time these rivers were sources of leisure activities, and at the edge of the city the small Paraibuna beach was used for fishing and leisure. Previous inhabitants related that they regularly interacted with the natural environment, especially with the rivers and streams, which provided them with a means of subsistence and direct contact with aspects of the local natural ecosystem.

During many decades, subsistence agriculture and sale of any surplus production was predominant in this region. Around 1950, families coming from the state of Minas Gerais began to buy large tracts of land and invest in dairy farming. The milk was sold to a dairy product company in Taubaté, which had a refrigerator tank at the municipal seat of Natividade. The cattle ranchers did not have the habit of contracting permanent workers, but rather hired sporadic help with jobs such as pasture maintenance, an occupation of many residents of the old city.

The Paraibuna Dam inundated 206 sq. km of territory of Natividade da Serra (14\% of its total). The settlements of Pouso Alto and Remédios and the district of Bairro Alto were affected and relocated to higher ground, nearer to Caraguatatuba than Natividade. The municipal seat was completely submerged, with only a wooden cross remaining, which was constructed in 1954 and installed on the highest hill in the city.

According to the Master Plan for the Paraibuna Reservoir (CESP, 1978), the construction of the dams that form the reservoir began in 1964 and ended in 1977. The Paraibuna hydroelectric plant began activity in 1978, but we were unable to affirm exactly when the municipal authorities were notified of the necessity of the destruction of the city.

The first allusion to the possibility of inundation of the municipal seat were found in official letters from the 1960s, with one in 1966 discussing the building of the dam without mentioning the disappearance of the city. Apparently, the executive powers were not officially informed about these plans, which is demonstrated by an official letter from 1968, four years after the start of dam construction. In this correspondence, which was addressed to the institution responsible for maintenance of state roads, it was requested that the stretch of the road that linked Natividade to Taubate not be abandoned, justified by the fact that the city would be condemned to disappear, since the inundation was planned to occur during 1970 and 1971, according to information reported by the media (Natividade da Serra, 1950-1980).

The process of transformation of this space also brought changes in the configuration of the population that inhabited the city. All the interviewees affirmed that many residents had serious doubts about the success of the new city, and for this reason abandoned the municipality (Table 2).

Table 2 shows a decrease in the total number of inhabitants in the municipality for the decade ending in 1980, after the change in location of the municipal seat. In comparison with the previous decade, the rural population was reduced a little more than $40 \%$, while the number of urban residents increased considerably. 
Table 2. Evolution of the population of Natividade da Serra, 1970-1980.

\begin{tabular}{lcc}
\hline & $\mathbf{1 9 7 0}$ & $\mathbf{1 9 8 0}$ \\
\hline RURAL POPULATION & 8,634 & 4,991 \\
URBAN POPULATION & 1,405 & 1,940 \\
TOTAL POPULATION & 10,039 & 6,931 \\
\hline
\end{tabular}

Source: Master Plan of the Paraibuna Reservoir (CESP, 1992, p. 11), attributed to the censuses of 1970 and 1980, Brazilian Institute of Geography and Statistics (IBGE).

The increase in the urban population is partially explained by the migration of residents of the rural zone whose properties were inundated or isolated by the dam and then took up residence in the municipal seat. Furthermore, as previously discussed, there was a large demand for plots of land in the new city, baptized Nova Natividade, by people from various regions of the state of São Paulo. Due to the scarcity of sources, it was not possible to precisely state the number of residents who left the city, or the number of new inhabitants attracted by the incentives provided by the municipal government. This situation created a paradox: abandon the municipality or be inserted into the developmentalist rationale of intervention in natural and social milieus of autochthonous populations that was heavily preached by the government during this period. Table 3 below shows evidence for this situation.

Table 3. Evolution of the indices of workers in different occupations in Natividade da Serra between 1970-1980.

\begin{tabular}{lccc}
\hline & $\mathbf{1 9 7 0}$ & $\mathbf{1 9 8 0}$ & VARIATION \% \\
\hline AGRICULTURE AND CATTLE RANCHING & 2,491 & 1,498 & -39 \\
INDUSTRY & 180 & 275 & 52.77 \\
RETAIL SALES & 29 & 54 & 86.2 \\
SERVICES & 145 & 363 & 150.34 \\
TOTAL & 3,888 & 4,760 & 23 \\
\hline
\end{tabular}

Source: Master Plan of the Paraibuna Reservoir (CESP, 1992, p. 12), attributed to the censuses of 1970 and 1980, Brazilian Institute of Geography and Statistics (IBGE).

Table 3 quantifies the decrease in workers occupied in different activities related to agriculture and cattle ranching - permanent or temporary - and the increase in the number of residents dedicated to activities for which permanent salaries were paid.

In Natividade, whether in the urban or rural zones, fishing was an activity linked to leisure and sustenance of families. The damming of the rivers provoked a change in the aquatic habitat, making it unhabitable for some endogenous species, and a few of these, typical of rapids, disappeared.

Species that were better adapted to the new aquatic environment were introduced through a conservation program called Ictiofauna, implemented by CESP in 1988. However, the fact that the dam affected natural reproduction areas created the necessity of maintaining a program of continuous artificial reproduction to maintain the supply of fish at constant levels. (Noffs and Salgado, 1992)

The changes in species and the supply of fish in Natividade da Serra modified the fishing habits in the municipality. CESP itself, in the Master Plan of the Paraibuna Reservoir, even recognized that the dam would make fishing unviable as an economic activity.

Subsistence agriculture, with the sale of excess production in the local market, was one of the most important economic activities in the municipality. The importance of this activity was registered in documents extracted from the state and catholic collections of documents and was 
also emphasized by the interviewees. The construction of the dam negatively affected the continuation of this activity in the new space because the waters inundated the varzea (floodplain) areas which were traditionally cultivated with species that were adapted to this area in Natividade da Serra. Currently, according to information obtained through the interviews, the local population needs to purchase agricultural products from neighboring cities to satisfy its demand.

\section{CONCLUSIONS}

The transformed space and its impact on the collective population resulted in changes in social groups involved in their daily actions and interactions. The disappearance of fertile cultivation areas and the modification of the aquatic habitat reduced traditional modes of subsistence of the majority of the local population, which resulted in increased dependence on official jobs regulated by labor laws, with salaries provided by the municipality. The adoption of this type of work altered the perception and use of time, which was reflected in several spheres of human activity and transformed ways of life.

Spatial and environmental modifications brought about in an abrupt manner and in the absence of dialogue, to which the local community was subjected, coexisted with the insertion of new members into the new city from diverse segments of the regional population. This changed the previous sociological profile of the local population, which was historically constructed in an autonomous and empirical manner. This research was not able to detect any record of explicit and organized resistance from autochthonous and dedicated groups that were against the paradigm of progress that was promoted by the governmental authorities during the period of the civil-military developmentalist dictatorship.

The implications of this radical modification of space were perceived by the new configurations of the collective identity. The population was forcibly made to initiate a new process of creation of a collective history and created forms of sociability and intervention in space, which resulted in its abandonment, through its own perception of developmentalist progress.

\section{REFERENCES}

AMADO, J.; FERREIRA, M. (orgs.). Usos \& abusos da História Oral. Rio de Janeiro: FGV, 2002.

BOSI, E. Memória e sociedade. Lembrança de velhos. São Paulo: Cia das Letras, 1994.

COMPANHIA ENERGÉTICA DE SÃO PAUlO. Plano Diretor do Reservatório de Paraibuna. São Paulo, 1978.

COMPANHIA ENERGÉTICA DE SÃO PAUlO. Plano Diretor do reservatório de Paraibuna. São Paulo, 1992. 94 p.

FAUSTO, B. História do Brasil. SP: EdUSP; Fundação para o Desenvolvimento da Educação, 1996.

FENELON, D. R. (org.). Pesquisa em história: cidades. São Paulo: Olho D’água, 2000.

FRANÇOIS, E. A fecundidade da história oral. In: AMADO, J.; FERREIRA, M. (orgs). Usos \& abusos da História Oral. Rio de Janeiro: FGV, 2002. p. 3-13.

GLÉNISSON, J. Iniciação aos Estudos Históricos. São Paulo: Difusão Européia do Livro, 1961. 
KHOURY, Y. A. Narrativas orais na investigação da história social. Projeto História: Revista do Programa de Estudos Pós-Graduados de História, n. 22, p. 79-104, 2001.

LEFEBVRE, H. Direito à cidade. São Paulo: Documentos,1969.

NATIVIDADE DA SERRA (SP). Registro de Ofícios Expedidos. Natividade da Serra, 19501980. p. 174; p. 56.

RICCI, F. Usinas Hidrelétricas - pequenas concessões: usina Félix Guisard - um estudo de caso. Dissertação (Mestrado em História Social). São Paulo: PUC, 1996.

RYKWERT, J. A sedução do lugar: a história e o futuro da cidade. São Paulo: Martins Fontes, 2004.

TUAN, Y. Espaço e lugar: a perspectiva da experiência. São Paulo: Difel, 1983. 